\section{OPEN ACCESS}

Citation: Abdulshakour S.T. (2020) Impact of Financial Statements on Financial Decision-Making. Open Science Journal 5(2)

Received: $25^{\text {th }}$ November 2019

Accepted: 26 $6^{\text {th }}$ December 2019

Published: $12^{\text {th }}$ June 2020

Copyright: (C) 2020 This is an open access article under the terms of the Creative Commons Attribution

License, which permits unrestricted use, distribution, and reproduction in any medium, provided the original author and source are credited.

Funding: The author(s) received no specific funding for this work

Competing Interests: The author has declared that no competing interests exists.
RESEARCH ARTICLE

\section{Impact of Financial Statements on Financial Decision-Making}

\author{
Saddeq T. Abdulshakour ${ }^{1 *}$ \\ ${ }^{1}$ University of Jeddah, Saudi Arabia \\ *Corresponding author: Saddeq Abdulshakour: S.abdulshakour@hotmail.com
}

\begin{abstract}
:
Objective: The study aimed to know impact of financial statements on financial decision-making, and the degree of benefit from them, and to identify what financial statements, what is its importance for the institutions within the framework of the Kingdom's Vision 2030 of ideas and trends, and to identify the contribution of financial statement analysis to financial decision-making.

Methodology: The study was based on the descriptive and analytical approach, and the study population consisted of all financial decision makers. The study was based on the questionnaire and consisted of the following axes (financial statements in companies, financial decision-making, the Impact of analysis of financial statements on financial decision-making). Findings: The financial statements are a key tool to know the financial position of the company, so they must be accurate and reliable before being published by management. The lack of credibility in the financial statements leads to mistrust in the company by investors and does not give them the possibility to diagnose and make sound decisions.
\end{abstract}

Keywords: Financial Statement, Analysis, Financial Decision, Financial Manager

\section{Introduction}

At present, the Foundation is one of the most important units for the establishment and formation of any economy, in a way that affects and is affected by the frustration in which it settles, and cannot live away from the changes and developments that are accelerating daily. whether direct or indirect impact on the institution and its growth, these changes have contributed 
significantly to the emergence of economic concepts for the administrative and financial aspects. This requires the entrepreneurs in these institutions to adapt to them and take them into account in trying to determine the status of the institution in the environment in which it operates. Among competitors based on scientific methods used in the decision-making process. This varies depending on the size of the institution and its activities and functions (Khawla, 2016).

As the world is witnessing contemporary developments, which cast a shadow on the patterns and trends of relations in many economic and social fields. it has followed these developments, and became a service activity concerned with providing information to various parties, whether internal or external dealing with economic unity. In the field of business environment, many problems have arisen for institutions, including accounting institutions, which is mainly due to the different accounting standards between countries, which led to the inevitability of increasing interest in accounting information, which is the results of the accounting system. This is the basis for any decision-making process, which is built to compare this information in many institutions at different stages of time, and this required the development of accounting function in standard methods, as well as the disclosure of accounting information, especially in relation to the financial outputs of institutions (Zager, 2006).

The financial accounting system is the backbone derived from the International Accounting Standards, which is based on a set of concepts and principles used as a framework for reference (Ben Omar, 2015), where the output of the financial accounting system in any institution consists of financial statements and reports. It aims primarily at providing information related to the financial situation of the institution, in addition to the results of its activities. It also contributes to clarifying the financial and monetary flows and changes and changes in equity. A lot of other information is added to these lists to complement the information included in these lists, through the disclosure of the various accounting methods and principles used by the institution or organization in preparing its own lists (Dabash, Khamili, 2017).

With the large size and multiplicity of institutions, and the multiplicity of direct and indirect parties to the activity of the institutions, the financial statements have become public and impartial to one category without another, which required some studies and analyzes of these lists in order to meet the needs of users of special information that allows for better financial decisions. The information provided by the lists is not accessible without the study and analysis of this information through financial analysis tools, whether in providing useful indicators that measure the financial capacity of the institution, or information useful in knowing the efficiency of management or the extent to which the economic institution exploits its economic resources. Financial analysis also helps to provide financial information that is useful in predicting financial failure, and the consequent critical decisions in how an organization operates. As the financial decision-making process is one of the most important organizational procedures and roles played by the members of the institution, and the decision-maker cannot do its work unless available to him information. This necessitates an indepth study and numerical analysis of the financial statements before any financial decision is taken, so that the manager can discover the strengths and best exploit, and identify weaknesses to take the necessary corrective actions (Ahlam, 2016).

In the Kingdom of Saudi Arabia, and within the framework of the efforts exerted to achieve the Kingdom's Vision 2030, the Kingdom seeks to develop the financial sector through several development programs, where the Council for 
Economic Affairs and Development launched an executive program concerned with the development of the financial sector to achieve the objectives of the Kingdom Vision 2030. This is to be a diversified and effective financial sector to support the development of the national economy, stimulate savings, finance and investment, and increase the efficiency of the financial sector to face and address challenges. By seeking to achieve financial inclusiveness, financial stability and transparency with regard to the financial statements and financial statements of companies, as this gives the financial statements of companies high quality and confidence generated by individuals make him think seriously about the Saudi investment environment as a stimulating environment characterized by the quality of information produced by the accounting system (Financial Sector Development Program Document, 2018).

In light of this interest, and in view of the objectives of the Kingdom's Vision 2030 with regard to its financial and economic sector, especially financial data and related information, a state of interdependence is formed based on the relationship between financial statements and analysis of efficiency and high quality, and financial decision-making. This is what we seek to study later.

\section{The problem of the study}

The financial statements are a reflection of the activity of the economic institution, and this is consistent with the perspective of economic and information systems in providing a broad overview of the activity of the economic unit, and that the results of this system are financial statements. Especially since its data is a formula indicative of the efficiency of economic activity or deterioration, and hence comes the role of financial analysis in the analysis of financial statements and interpretation in order to ensure that the results of financial analysis match with the objectives set. Especially with the strength of economic performance closely linked to the decisions of the administration, where these decisions require a choice between alternatives that are based mainly on the financial analysis of these lists, and examined the financial situation and the movement of resources in it (Al-Obeidi and Abdul Razek, 2016). The Dabash and Khamili (2017) study indicated that financial statements are of great importance in making investment decisions. It pointed out that any investment decision is based on a set of disclosures for accounting and financial information obtained through the financial statements, and the study of Ahlam (2016) concluded that the financial statements play a significant role in financial decision making. In order to achieve the overall objectives of the financial decision-making process, the decision-maker studies the information contained in the lists, understand, transmit and interpret them through the indicators of financial analysis, to reach the real financial situation of the institution and take appropriate financial decisions. Khawla study (2016) indicated that financial analysis has the full ability to guide the institution, especially in taking financial decisions, and to avoid risks and obstacles. She also pointed out that financial analysis contributes to determining the status of the financial institution. Proceeding from the efforts made towards the realization of the Vision 2030, and in the light of previous studies and relevant research. In the context of what was addressed and the document of the Financial Sector Development Program, the main implications of which were the decline in the financial service, the weak financial culture and the weak interfaces. The absence of specific criteria in the analysis of financial 
statements, which depends on the process of financial decision-making in institutions and considered as a difficult thing, cannot be given a full and correct decision without a good analysis of financial statements. it is considered the most important catalyst for decision makers. Through its tools used to give the true status of the institution. therefore, the financial analysis of the budget and financial statements and balances of the institution represents the appropriate framework for conducting the diagnostic process. Since each difference in the status and decisions of the institution will appear through some financial indicators, and therefore the problem of research in the following key question:

"What is the impact of analyzing financial statements to make financial decisions?"

The main question is subdivided into the following sub-questions:

1.What are the stages of financial decision-making based on the analysis of the Corporation's financial statements in the light of the Kingdom's Vision 2030?

2.To what extent does the analysis of financial statements contribute to financial decision-making in the light of the Kingdom's Vision 2030?

3.Does the use of financial statement analysis differ depending on the size of the entity (large-medium-small)?

4.Is there a statistically significant relationship between the use of financial reports and financial decision-making?

\section{The importance of the study}

1. Trying to add a new reference on this subject, and enriching the Arab library with such references, which suffers from a lack and scarcity in studies and researches that have dealt with this subject, especially as it deals with this subject in the future linked to the Kingdom's development plan of vision (2030).

2. Desire to study the financial statements according to the financial accounting system and to know the variables that have occurred in the financial statements.

3. The impact of decision-makers on the use of results from the analysis of financial statements to give accuracy in the financial decisions taken.

\section{Objectives of the study}

1. Know the impact of analyzing financial statements on financial decisionmaking, and the degree of benefit from them, as financial analysis is one of the most important means upon which the results of institutions. In addition, it is built upon in the case of future plans, using the analysis related to financial statements, as it is the real database about the company and its resources and movements of balances in it, which helps in reaching sound financial decisions based on clear scientific and accurate analysis.

2. Identify the financial statements and their importance to the institutions within the framework of the Kingdom's vision of 2030.

3. Identify how decision makers can benefit from the analysis of financial statements within the framework of the Kingdom's Vision 2030. 
4. Identify the stages of financial decision-making based on the analysis of financial statements of the institution in the light of vision 2030 .

5. Identify the contribution of analysis of financial statements to financial decisions.

6. Determine if there is any effect of using financial statement analysis according to the size of the establishment (large-medium-small).

\section{Theoretical framework and previous studies}

\section{First: the theoretical framework}

Financial Statements

The concept of financial statements

Sami (2012) defined it as "a complete set of financial and accounting documents that allow a fair picture of the financial position, performance and treasury of the institution at the end of the session".

The researcher defines it procedurally as: "Reports include clarifications related to the financial situation of the institution during a period of time, or a specific period of time, where it is organized according to logical procedures. It helps to convey information about the financial elements of the company and show them at a particular moment, to help in making financial decisions, within the framework of financial trends in light of the Kingdom's Vision 2030".

\section{Types of financial statements}

The types of financial statements are categorized into several categories. The following is a review of the type of financial statements (Matar, 2006):

- Income statement: A statement or financial report showing the results of an entity's operations, including the entity's revenues and expenses, the difference between which represents the net profit or loss over a given period of time.

- Statement of financial position: A financial statement that shows the financial position of the entity including the assets and liabilities of the entity, as well as equity at a specific date through this list, the company's assets and liabilities are recognized. The size of the Company's cash, liquidity and ability to meet its obligations are also analyzed.

- Statement of changes in equity: Statement of changes in equity is the link between the statement of income and the statement of financial position. it is determined by monitoring and tracking changes in equity items from the beginning to the end of the financial period, and are presented on an accrual basis.

- Statement of Cash Flows: This is a statement or financial report showing all cash inflows and outflows from a business over a specified period of time and classified according to operational, investment and financing activities. 
Elements of financial statements

The elements of the financial statements are divided into (Ahmed, 2010):

1. Assets: These are resources controlled by the enterprise as a result of past events and operations, and result in future benefits for the entity.

2. Liabilities are liabilities to the Corporation towards third parties, but because of the result of the assets of the enterprise, i.e. the remaining part of the assets of the enterprise after the payment of all obligations to others, and represent (assets-liabilities).

3. Equity: represents the owners' claims to the assets of the enterprise. That is, the remaining part of the assets of the enterprise after payment of all obligations to others, representing (assets-liabilities).

4. Profit: An increase in equity due to increased economic benefits, which is not related to the normal activity of the Corporation such as: gains on the sale of a fixed asset.

5. Expenses: The lack of economic benefits during a period in the form of cash outflows as a result of the sale of a commodity or the provision of a service, it is the cost of obtaining revenue.

6. Losses: The decrease in equity due to economic benefits, which is not related to the normal activity of the Corporation such as losses arising from the sale of a long-term investment.

7. Withdrawal: The value of what the owners receive from the establishment for personal use, not directly related to the normal activity of the establishment, such as cash withdrawals or withdrawals of goods.

8. Net income: The increase in the Corporation's revenues over the expenses related to these revenues during a period.

9. Net loss: An increase in the expenses of the Corporation over income related to it during a period.

The importance of financial statements

The importance of financial statements can be highlighted in three main elements (Hamdan, 2013):

First: a communication tool: the role and role of the financial statements in this area is to convey a comprehensible message to the user of accounting information about the activity of the institution and the results of it are thus: a means to link relations between the institution and suppliers, customers and banks, and a means to provide information to the various sections of the institution, workers, analysts and researchers.

Second: a means in assessing performance: where financial statements help in assessing the performance of management and governance on the efficiency and use of resources at its disposal, used in judging: the financial position of the institution, and the progress in achieving the objectives of the institution.

Third: means in making the decisions: Financial statements help management and various parties dealing with the institution in making the necessary decisions where: Used in making decisions on how to spend resources in the future, and used from other parties that have a direct relationship with the institution such as: suppliers, customers, and banks in guiding the future of their relationships with them. 
Objectives of the financial statements

The objectives of the financial statements are as follows (Ahlam, 2016):

1. To present all the figures, information and financial statements of the Corporation for a certain period of time, to give an accurate indication of the financial position of the Corporation, and to extract the results of the operations of the Corporation during a given financial period.

2. Identify the assets and assets of the institution, whether long-term or short-term, and determine the value of changes in assets and liabilities and balance between them, and extract the most likely aspect, the expression of the assets of the institution and its obligations and representation in cash units in circulation.

Characteristics of financial statements

The characteristics are qualities that make the information in the financial statements useful to users, and enable them to gain their trust, and therefore the main characteristics are the following (Hanan and Baldawi, 2009):

1. Appropriateness: It is intended that the accounting information is relevant or relevant to the decision taken.

2. Reliability: This means that you can rely on the information provided, that is, make the decision maker trust.

3. Comparability: means the provision of accounting information that allows comparisons between similar institutions in the same conviction. This increases the usefulness of information, as it allows for an assessment of the status and status of a given institution compared to similar institutions. Proper comparability requires that similar accounting methods be used by different institutions to handle the same processes or events.

4. Consistency: This means comparing the results of the same organization from one accounting period to another.

5. Understandability: It means direct understanding by users, and for this purpose users are supposed to have a reasonable level of knowledge of business, economic activities and accounting.

Financial Manager

The definition of financial manager

Al-Nabahin (2008) defined him as: "The chief administrative officer in charge of the financial activity in his project, and one of the important members of the senior management responsible for managing the initiation. He is responsible for managing the financial department with its administrative and technical dimensions".

Abu Kuhail (2014) is also known by the Financial Manager as: "The person in charge of the company who organizes the work in the planning department, which leads to the timely delivery of the right information to the decision makers. He is the person who supervises the preparation of planning lists and planning budgets in addition to any reports or information needed by management" 
Duties of the Financial Manager

The Financial Manager is responsible for overseeing the financial affairs of the Corporation, having several functions, including (Yousef, 2012):

1. Analysis of financial statements: This function is concerned with converting the financial statements into a form or pattern so that they can be drawn to know the strengths and weaknesses of the financial position of the project, plan future financing operations and assess the need to increase the production capacity of the institution, and thus estimate the amount of funding required.

2. Determine the structure of the project assets: where the financial manager determines the structure and types of assets as they appear in the statement of financial position, and this means determining the amount of money invested in fixed assets and current assets, and after determining the structure of assets determines as much as possible the optimum investment size in each type of current assets, identify the fixed assets to be used, and when the latter become technically obsolete and then replaced or upgraded.

3. Identifying and shaping the financial structure: where there are two types of special financial decisions, the first type of decisions relates to the determination of the appropriate mix of short and long-term financing. This is one of the most important financial decisions because of its impact on profitability and public liquidity; loans are long-term or short-term at a given time. Conditions may impose certain types of decisions and some may require extensive analysis and in-depth consideration of available alternatives, costs and implications.

The importance of analyzing financial statements in making financial decisions

The information in the financial statements is considered to be the most influential in decision-making, and is of good quality because of its characteristics as a link between objectives and measurement standards, which are used to assess the level of quality of information. Decision-makers can choose between different alternatives by using the qualitative and reliable characteristics of accounting information (Al-Mahhali, 2009). The primary function and ultimate goal of the financial statement analysis process is to increase knowledge and reduce uncertainty among users of this information, helping them to make meaningful decisions within an objective framework. The financial statements are therefore the best source of information, and this is because this quantitative blame is verifiable, and one of the main objectives of the financial statements is to provide information for decision-making. The analysis of financial statements plays an important role in the preparation of decisions that concern the financial aspect of the institution, especially on achieving an effective balance between the elements of assets to work more efficiently, and the elements of liabilities to reach the lowest cost of funds invested between the centers of assets and liabilities, and up to the balance of the institution decision (Abu Huwaidi , 2011). The role that financial information plays in financial decision-making is therefore fundamentally linked to the horizon. It is well known that accounting information plays a greater role in short-term decisions than in long-term decisions. Information forms the key elements in decision-making and forms a link between accounting and decision-making (Sufian and Sharaa, 2002). 
Making financial decisions

The concept of financial decision making

Jalili (2013) defines it as: "The whole process of taking the steps, steps and foundations followed in an accurate scientific way that ensures the flow of information and analysis to form possible alternatives in order to achieve a particular goal or solve a particular problem so that the process includes the optimal alternative, a decision that achieves efficiency and effectiveness."

The researcher knows it procedurally: "The cognitive process that is built by analyzing the data in the financial statements, to derive the best and most appropriate options that suit the company and in line with the directions of the Kingdom's Vision 2030, through its values, tradeoffs and beliefs, to overcome problems and plan the future with ideal solutions".

Characteristics of the financial decision-making process

The decision-making process has several characteristics that can be summarized as follows (Ayyash, 2008): The decision-making process is realistic. The decision-making process is influenced by humanitarian factors stemming from the behavior of persons and that any financial decision must be an extension from the present to the future. The decision-making process is general, it includes most institutions and is inclusive of all administrative positions in the institution, in addition to the process consists of a series of sequential steps, and it is a process affected by various environmental factors.

Types of financial decisions

There are three types of financial decisions in an economic institution:

Financial decision

a.The concept of a financial decision: A financial decision is defined as a decision that looks at how the institution obtains the necessary funds for investments (Zogheib and Boujad, 2009). It is also the presentation of funds in the institution, which determines the optimal mix of different sources of financing, whether owned or borrowed (Hanafi, 2005).

b.Types of financial decisions

Financial decisions are divided into two parts (Al-Naimi and Al-Tamimi, 2009):

- Decisions means determining the appropriate mix of short- and long-term financing, which is one of the most important decisions affecting profitability and liquidity.

- Decisions to determine which is more beneficial for the institution in shortterm or long-term loans at a specific time through in-depth study of available alternatives and the cost of each alternative and its long-term implications.

c.Factors influencing the funding decision

Some of these factors (Matar, 2006) are the element of appropriateness, i.e. the source of funding is appropriate to the area in which the funds are used, the cash position of the institution to the decision maker, and its policies in managing this liquidity. In addition to the lender's restrictions on the borrower, which 
usually relates to collateral provided, as well as tax benefits, external sources of finance generate tax savings that reduce the weighted average cost of funds.

Investment decision

a.The concept of investment decision: The investment decision is one of the most important and difficult decisions taken by management in the institution, as these decisions aim to determine the optimal structure of the size of investment, as these decisions affect the survival and continuity of the institution (Chiha, 2009).

b.The basic elements of the investment decision: The successful investment decision is based on the following basic elements (Al Shaib, 2011):

- The principle of multiple investment options: Since the funds invested huge, it is necessary to choose many alternatives and preferably not less than three, and this in order to gain decision-making flexibility to make the right decision.

- The principle of appropriateness: that is, the investment project chosen must correspond to the financial potential of the institution.

- The principle of diversification of investment risk: through the diversification of investment instruments, which leads to reduce the risk, so that the loss in one instrument is compensated by profit in another instrument.

c.The stages of investment decision-making: The process of investment decision-making must go through the following stages (Al Shaib, 2011):

- The stage of preparing the projects or the initial idea of the project: This stage relates to the objectives laid down by the investor and which he wishes to achieve, so that the projects are initial ideas seeking to achieve the desired objectives.

- Project Evaluation Phase: At this stage, the investment cost and expected return, as well as the cash inflows and outflows of the project over its economic lifetime, are assessed through the various criteria for selecting the optimal project.

- Project selection stage: At this stage, the optimal alternative is chosen based on different methods of differentiation between projects, under the principle of choosing an investment that achieves a higher return on capital than the cost of investment, with a minimum acceptable return.

- Project implementation phase: At this stage, all the funds required by the selected project and the preparation of the various budgets related to it, in addition to the time of implementation and completion and the phase of the trial operation.

\section{Dividend distribution decisions}

a.The concept of dividend distribution decision means the portion of the net profits which the Corporation shall distribute to its shareholders according to the percentage of shares they hold. The Board of Directors may declare at any time. Distribution is an option for the Board and not a legal obligation, and the dividend policy is built to support the financial structure through an increase in private funds through undistributed profits (Al Naimi and Tamimi, 2009).

b.Types of dividend distribution policies: Overall, there are three dividend distribution policies that can be cited as follows (Al-Ali, 2010): 
- A policy based on a fixed dividend ratio: Dividend distribution means the percentage of dividends to be distributed in the form of cash to shareholders, calculated by dividing the number of dividends by profitability, and calculated by dividing net profits by the number of shares issued.

- Regular dividend policy: This policy is based on the distribution of fixed amounts to shareholders in each period in which the dividend decision is made, which makes investors feel a high degree of confidence in the image of the stock in the financial market.

- Few regular amounts with unusual dividends: This policy is carried out in institutions characterized by fluctuations in their periodic dividends, by distributing fixed and small amounts to their shareholders in the periods of dividend decision making.

Stages of financial decision making

Stage 1: Diagnosing the nature of the problem:

It is the first step in the decision-making process. Diagnosing the problem means identifying the real problem and determining its dimensions and investigating the main cause of the emergence and knowledge of its causes, purposes and effects. It also refers to the independent variables that make the organization's performance incompatible with the set goal (Abdel Hakim, 2013).

Stage 2: Problem analysis and finding alternatives:

This stage is meant to inspect or investigate different solutions to solve the problem that was diagnosed accurately in the first stage. It assumes proposing different alternatives or solutions to the diagnosed problem. This depends on the analyst's ability to analyze and innovate to find new solutions based on the previous experience and the information and expertise of others.

Stage 3: Evaluation of Alternatives:

The difficulty of this stage is that the advantages and disadvantages of these alternatives are not clearly evident during the study of the problem, but they do appear in the future and the evaluation is supposed to be in accordance with criteria and objective grounds in order to indicate the advantages and disadvantages of each of these alternatives (Jalila, 2009).

Stage 4: Decision Making (Choosing the Best Alternative):

At this stage, the best option is chosen from among the available alternatives. Here, the manager makes the decision based on the best alternative, but before that must make sure that this alternative fit all the requirements and other factors of the problem that were not taken into account during the previous stage (Khaled, 2014).

Stage 5: Implementation and Follow-up of the Decision:

The nature of the decision is characterized by its implementation by others, and the director only at this stage to guide the executives, showing them the work that they have to do. The role required of each but they are the resources available for implementation, and this requires the understanding of the decision by the implementers and motivate them to perform. This is done through the principle of participation in decision-making where the implementers feel that the decision of their own making, and it is very important that the objectives of the decisions are in line with the goals and aspirations of those who implement them, which is reflected in raising the level of performance and improve it. 
Assistive techniques in financial decision making

The decision-maker uses several analytical methods that help him in the decision-making process, often called quantitative decision-making methods, which are centered on the following methods (Nawaf, 2003):

1. Linear programming method: Linear programming is defined as a mathematical method that aims to estimate the optimal situation of the uses of specific resources in the organization, and despite the widespread use of linear programming to solve problems. However, there are areas where this method is difficult to use because the relationship between variables is difficult to put in the form of proportions, and to avoid this problem emerged so-called quad programming and dynamic programming.

2. Decision tree: It is in the form of a tree with three variables: alternatives for solving the problem in question, probabilities representing expected gain or failure, and values representing total expected returns over a specified period.

3. Operations Research: It is an application of scientific methods, methods and arts to solve the problems facing decision-makers in a way that ensures the best results and objectives required.

4. Critical Path Method: This method is based on the study of the early and late time for the performance of various activities, with the calculation of excess time, if any, and represents the critical path to the end of the plan without a surplus.

Probability theory: This theory is based on the belief supported by experience, that an event can be predicted by a certain pattern, if there is a difference in the probability estimate it can be predicted, and thus the expected probability becomes information can be based on instead of delving into the unknown.

5. Prediction: relates to the future to set goals and achieve them, relying on this method will be through the part to the methods of time series and regression models.

\section{Second: Previous Studies}

1.Dabash and Khamily (2017): "The Contribution of Financial Statements to Investment Decisions in the Stock Market: A Case Study of Investors in the Algiers Stock Exchange"

The study aimed to identify the contribution of financial statements in making investment decisions in the stock market. The study used the descriptive and analytical method to suit the subject of the study. The study used the questionnaire as a tool to obtain the responses of the sample members. The sample of the study was limited to 85 users of financial statements (investors, shareholders). The study concluded with a number of results, the most important of which are: The financial statements have great importance in making investment decisions. The respondents also pointed out that the financial statements are the most important sources of information they need when making their investment decision. The study also pointed out that there is a positive and statistically significant role between the financial statements and investment decisions in the stock market.

2.Peltoniemi, (2017): "The Role of Financial Statements Analysis in MFI Investment Decisions" 
The objective of this study was to assess the impact of financial statement analysis on the investment decisions of Bapkel in Yaoundé, Cameroon. The study followed the descriptive approach. The study sample consisted of 60 employees in the financial department of the organization, while the sample of the study was limited to 15 employees. The study used observation and personal interview as a study tool. Most of the organizations did not use the financial statement to make investment decisions, and almost all employees were aware of the role of financial reporting in investment decisions. In light of the previous results, the study recommended the need to expand and direct scientific research towards the variables of this study, but with new contents and dimensions, especially in new cities and regions as well. It also recommended organizations that do not follow methods of financial disclosure and review of financial statements.

3.Ahlam (2016): "The Role of Financial Statements Analysis in Financial Decision Making: A Case Study of the Great Mills of the South Omash Corporation"

The study aimed to highlight the importance of financial analysis for financial decision-making, and to identify the reality of financial statements and the extent of their expression of the real situation of the institution, and to show the role of financial statements in the financial decision-making process. In addition to trying to show and highlight the importance of financial statements in the economic institution. The study followed the descriptive analytical and case study approaches in the pursuit of results, by analyzing these statements by calculating some financial indicators that illustrated the relationship between the various elements of the financial statements. The study came out with a number of results, the most important of which are: Financial statements have a big role in financial decision-making. And make appropriate financial decisions. The results also indicated that the financial statements are a reflection of the financial position of the institution costs. The results also indicated that the financial statements presented at the Southern Mills Corporation provide comparable financial information, which helps its users to make their economic decisions.

4.Ben Omar (2015): "The Role of Financial Statements in the Financial Accounting System in Financial Decision Making: A Case Study of the Royal Mondial Foundation in the Valley (2013)"

The study aimed to identify what the financial accounting system is, how the financial statements are presented according to the financial accounting system, clarify what is meant by the decision-making process, and determine the role that financial analysis plays in the decision-making process. The study followed the descriptive approach of the theoretical aspects, in addition to the case study approach, using financial analysis tools to analyze the data obtained through the financial statements of the institution. The study came out with a number of results, the most important of which are: The presentation of the financial statements facilitates the investor's decision to invest or not. It also pointed out that the decision to distribute dividends is one of the most important information that raise the price of the stock of the institution in the financial market. In addition, the investment decision is considered a strategic decision and important in the life of the institution because of the direct link between the company's property and risks to the market, which requires a good study and in-depth.

5.Nkuhi (2015): "The Role of Financial Data in Investment Decision Making"

The study aimed at the role and impact of financial statements on investment decisions. The study also followed the content analysis methodology of the study, through what is mentioned in the previous literature and field studies. The results indicated that sound financial statements make the decision of investors 
more confident in their decision-making, as well as the knowledge of the sample of the study of financial variables. The study recommended that research should be conducted on samples of both sexes, and encourage the use of financial statement analysis in the investment decision.

\section{Methodology}

\section{Study Approach}

The study relied on the descriptive analytical method, which is considered one of the most used methods in the study of social and human phenomena and because it fits the phenomenon under study. A descriptive analytical approach is defined as a method of analysis based on sufficient and accurate information on a specific subject within limited time periods in order to obtain practical results that are objectively interpreted in line with the actual data of the phenomenon (Obeidat et al., 1999, p. 46).

\section{Study Population and Sample:}

The population of the study consists of all financial decision-makers. The study was based on a simple random sampling method. A random sample size (70) was taken from the financial decision-makers, (68) questionnaire was valid for analysis, a rate of recovery of $97 \%$. Table (1) shows the characteristics of the respondents according to personal data:

Table 1: Distribution of Study Sample by Personal information

\begin{tabular}{|c|c|c|c|}
\hline Variable & Category & Number & Percentage \\
\hline \multirow{3}{*}{ Qualification. } & Less than BS & 33 & 48.5 \\
\hline & M.A. & 31 & 45.6 \\
\hline & Ph.D. & 4 & 5.9 \\
\hline \multicolumn{2}{|l|}{ Total } & 68 & 100.0 \\
\hline \multirow{2}{*}{ Gender } & Male & 45 & 66.2 \\
\hline & Female & 23 & 33.8 \\
\hline \multicolumn{2}{|l|}{ Total } & 68 & 100.0 \\
\hline \multirow{4}{*}{ Years of service } & Less than 5 years & 34 & 50.0 \\
\hline & 5 to 10 years & 16 & 23.5 \\
\hline & 10 to 15 years & 10 & 14.7 \\
\hline & More than 15 & 8 & 11.8 \\
\hline \multicolumn{2}{|l|}{ Total } & 68 & 100.0 \\
\hline \multirow{4}{*}{ Age } & Less than 25 years & 9 & 13.2 \\
\hline & 25 to 35 years old & 43 & 63.2 \\
\hline & 36 to 45 years & 10 & 14.7 \\
\hline & More than 45 years & 6 & 8.8 \\
\hline \multicolumn{2}{|l|}{ Total } & 68 & 100.0 \\
\hline \multirow{2}{*}{ The scope of your company } & Small & 15 & 22.1 \\
\hline & Medium & 17 & 25.0 \\
\hline
\end{tabular}




\begin{tabular}{|c|c|c|c|}
\hline & Large & 36 & 52.9 \\
\hline \multicolumn{2}{|l|}{ Total } & 68 & 100.0 \\
\hline \multirow{2}{*}{$\begin{array}{l}\text { Do you have a qualification or job related to financial } \\
\text { management? }\end{array}$} & Yes & 47 & 69.1 \\
\hline & $\mathrm{No}$ & 21 & 30.9 \\
\hline \multicolumn{2}{|l|}{ Total } & 68 & 100.0 \\
\hline
\end{tabular}

\section{Study tools}

The researcher used the questionnaire, which consisted of two main sections. The first section consists of the personal data of the respondent (educational qualification, gender, years of service, age, scope of the company, and the job related to financial management), where the second section of the following:

- The first axis: financial statements in companies, and this axis consists of (16) paragraph expresses.

- The second axis: making financial decisions in companies, and this axis consists of (17) paragraph expresses.

- The third axis: the effects of the analysis of financial statements on financial decision-making, and this axis consists of (15) paragraph express.

\section{Measuring the validity of the study tool}

Virtual validity: The method of virtual validity was used, in order to ensure the validity of the questionnaire and suitability for research purposes, by presenting in its initial form to a group of arbitrators (50) arbitrators with experience in the field of finance and finance. A percentage greater than $75 \%$ to $100 \%$ was obtained for all terms except three terms with approval rates between $53 \%$ and $59 \%$. The terms were amended to fit the scope of the phrase and therefore the data collection form passed the validity of the arbitrators and was valid.

Validity of Internal Consistency: Internal consistency means the consistency of each paragraph of the resolution with the axis to which this paragraph belongs. Consequently, the correlation coefficients between the score of each paragraph and the total score of the axis to which they belong were calculated.

a.Validity of the internal consistency of the first axis paragraphs:

Correlation coefficients were calculated between the score of each paragraph and the total score of the axis. Table (3) shows the results of the validity of the internal consistency of all paragraphs of the first axis.

Table 2: Validity of the internal consistency of the paragraphs of the themes of the study

\begin{tabular}{|c|c|c|c|c|c|c|c|c|}
\hline \multicolumn{3}{|c|}{ Paragraphs of the first axis } & \multicolumn{3}{c|}{ Paragraphs of the second axis } & \multicolumn{3}{|c|}{ Paragraphs of the third axis } \\
\hline$\#$ & $\begin{array}{c}\text { Correlation } \\
\text { coefficient }\end{array}$ & $\begin{array}{c}\text { Significance } \\
\text { level }\end{array}$ & $\#$ & $\begin{array}{c}\text { Correlation } \\
\text { coefficient }\end{array}$ & $\begin{array}{c}\text { Significance } \\
\text { level }\end{array}$ & $\begin{array}{c}\text { Correlation } \\
\text { coefficient }\end{array}$ & $\begin{array}{c}\text { Significance } \\
\text { level }\end{array}$ \\
\hline 1 & $.618^{* *}$ & .000 & 1 & $.754^{* *}$ & .000 & 1 & $.588^{* *}$ & .000 \\
\hline 2 & $.622^{* *}$ & .000 & 2 & $.540^{* *}$ & .000 & 2 & $.698^{* *}$ & .000 \\
\hline 3 & $.702^{* *}$ & .000 & 3 & $.658^{* *}$ & .000 & 3 & $.632^{* *}$ & .000 \\
\hline 4 & $.503^{* *}$ & .000 & 4 & $.618^{* *}$ & .000 & 4 & $.736^{* *}$ & .000 \\
\hline 5 & $.348^{* *}$ & .004 & 5 & $.471^{* *}$ & .000 & 5 & $.730^{* *}$ & .000 \\
\hline
\end{tabular}




\begin{tabular}{|c|l|l|c|c|c|c|c|c|}
\hline 6 & $.576^{* *}$ & .000 & 6 & $.529^{* *}$ & .000 & 6 & $.700^{* *}$ & .000 \\
\hline 7 & $.476^{* *}$ & .000 & 7 & $.531^{* *}$ & .000 & 7 & $.660^{* *}$ & .000 \\
\hline 8 & $.668^{* *}$ & .000 & 8 & $.729^{* *}$ & .000 & 8 & $.609^{* *}$ & .000 \\
\hline 9 & $.589^{* *}$ & .000 & 9 & $.644^{* *}$ & .000 & 9 & $.752^{* *}$ & .000 \\
\hline 10 & $.522^{* *}$ & .000 & 10 & $.703^{* *}$ & .000 & 10 & $.700^{* *}$ & .000 \\
\hline 11 & $.597^{* *}$ & .000 & 11 & $.553^{* *}$ & .000 & 11 & $.675^{* *}$ & .000 \\
\hline 12 & $.702^{* *}$ & .000 & 12 & $.599^{* *}$ & .000 & 12 & $.635^{* *}$ & .000 \\
\hline 13 & $.719^{* *}$ & .000 & 13 & $.689^{* *}$ & .000 & 13 & $.727^{* *}$ & .000 \\
\hline 14 & $.653^{* *}$ & .000 & 14 & $.544^{* *}$ & .000 & 14 & $.619^{* *}$ & .000 \\
\hline 15 & $.540^{* *}$ & .000 & 15 & $.591^{* *}$ & .000 & 15 & $.680^{* *}$ & .000 \\
\hline 16 & $.782^{* *}$ & .000 & 16 & $.608^{* *}$ & .000 & 16 & & \\
\hline & & & 17 & $.580^{* *}$ & .000 & & &
\end{tabular}

* Statistical function at significance level 0.01 .

It is clear from Table (2) that all paragraphs of the first axis are correlated statistically significant at the level of significance 0.01 to the total degree of the axis. The correlation coefficients for these paragraphs ranged from 0.348 to 0.782 . The correlation coefficients for the second axis paragraphs ranged between 0.471 and 0.754 , whereas the correlation coefficients for the third axis paragraphs ranged between 0.588 and 0.752 . This indicates that there is a validity of internal consistency in the paragraphs of the first, second and third axis, which supports the validity of the data collected from the study sample in this regard.

\section{Study tool stability}

Alpha Cronbach and Split _ Half were used to calculate data stability, as follows:

a.Alpha Cronbach stability

Table 3: Stability of the study tool by Alpha Cronbach method.

\begin{tabular}{|l|c|c|}
\hline \multicolumn{1}{|c|}{ Axis } & Number of paragraphs & $\begin{array}{c}\text { Coefficient of Alpha } \\
\text { Cronbach }\end{array}$ \\
\hline The first axis: financial statements in companies & 16 & 0.876 \\
\hline The second axis: making financial decisions in companies & 17 & 0.891 \\
\hline $\begin{array}{l}\text { The third axis: the effects of analysis of financial statements } \\
\text { on financial decision-making }\end{array}$ & 15 & 0.913 \\
\hline All axes of the questionnaire & 48 & .950 \\
\hline
\end{tabular}

It is clear from Table (3) that the value of the stability factor Alfakrnbach to identify "the effects of analysis of financial statements from a financial perspective for financial decision-making" (0.950), which means that the study tool has a high degree of stability. This indicates the validity of the data collected from the study sample in this regard. 


\section{(4.4) Verify data moderation}

The normal distribution of data is an important condition for the use of Parametric tests. To verify the condition of the study variables, the KolmogorovSmirnov test was used. The results are as shown in the following table.

Table 4: Natural distribution test of study variables

\begin{tabular}{|c|c|c|}
\hline \multirow[b]{2}{*}{ Axis } & \multicolumn{2}{|c|}{ Kolmogorov-Smirnov } \\
\hline & Test statistic & $\begin{array}{l}\text { Probability } \\
\text { value }\end{array}$ \\
\hline The first axis: financial statements in companies & .076 & .200 \\
\hline The second axis: making financial decisions in companies & .092 & .200 \\
\hline $\begin{array}{l}\text { The third axis: the effects of analysis of financial statements } \\
\text { on financial decision-making }\end{array}$ & .105 & .060 \\
\hline All axes of the questionnaire & .063 & .200 \\
\hline
\end{tabular}

Table (4) shows the result of the Kilmgrove-Simmer Nove test to verify the normal data distribution condition. Where the test result to achieve the condition of the normal distribution of the variables of the study. This enables us to use appropriate laboratory tests.

Statistical methods used in data processing:

The statistical analysis program (SPSS v.23) was mainly relied on to enter and analyze the study data, using the necessary statistical methods. To achieve the objectives of the study these methods were as follows:

- Frequencies and Percentages: for the purpose of describing the personal and practical data of the sample.

- Mean: to find out how high or low the responses of the respondents on the paragraphs and axes of the study.

- Standard Deviation: To identify the extent of deviation of the responses of the study members of each paragraph from its mean, the closer the value of zero concentrated responses and the lower dispersion.

- Alpha Cronbach and Split_Half: to measure data stability.

- Pearson Correlation Coefficient: To measure the validity of the internal consistency of the study paragraphs, and the structural validity of the study axes.

- Kolmogorov-Smirnov test: to check the condition of normal distribution of data.

- One Sample T-test: to check the existence of statistically significant differences in the average of the respondents of the sample of the total average for each paragraph of the questionnaire, and the total score for each axis.

- Independent Samples Test: To check for statistically significant differences in the average sample answers on the study axes, attributed to variables (type, do you have a qualification or your job related to financial management).

- One-way ANOVA: To verify the existence of statistically significant differences in the average answers of the respondents on the themes of the study, attributed to variables (educational qualification, number of years of service, age, size of the company). 


\section{Analysis of the results}

Analysis of the results related to the first axis (financial statements in companies):

Table 5: relative weight and arrangement for each paragraph of the first axis.

\begin{tabular}{|c|c|c|}
\hline Paragraph & $\begin{array}{l}\text { Relative } \\
\text { weight }\end{array}$ & Ranking \\
\hline The credibility of the financial statements is verified before being published. & $87.6 \%$ & 4 \\
\hline $\begin{array}{l}\text { The financial statements are verified by the auditors before being presented to the } \\
\text { beneficiaries. }\end{array}$ & $88.2 \%$ & 3 \\
\hline The financial statements present various trends related to liquidity and profit. & $82.1 \%$ & 11 \\
\hline $\begin{array}{l}\text { The financial statements are used to identify the future of the organization and } \\
\text { management. }\end{array}$ & $83.5 \%$ & 9 \\
\hline $\begin{array}{l}\text { The financial statements are a key tool to know the financial position of the company, so } \\
\text { be sure of their accuracy and credibility before they are published by management. }\end{array}$ & $92.1 \%$ & 1 \\
\hline $\begin{array}{l}\text { The lack of credibility in the financial statements leads to mistrust in the company by } \\
\text { investors, and does not give them the possibility to diagnose and make sound decisions. }\end{array}$ & $90.6 \%$ & 2 \\
\hline $\begin{array}{l}\text { The lack of credibility in the financial statements leads to a lack of confidence in the } \\
\text { company by the government agencies. }\end{array}$ & $85.0 \%$ & 7 \\
\hline The reliability of the financial statements is confirmed by multiple accounting books. & $81.8 \%$ & 12 \\
\hline $\begin{array}{l}\text { Manual financial statements are not considered a primary source of reference when there } \\
\text { is uncertainty about the reliability of financial statements prepared and published } \\
\text { through information technology. }\end{array}$ & $67.4 \%$ & 15 \\
\hline $\begin{array}{l}\text { The beneficiary of the financial statements is interested in the results presented only } \\
\text { regardless of their accuracy. }\end{array}$ & $64.4 \%$ & 16 \\
\hline $\begin{array}{l}\text { The external auditor shall endeavor to increase the credibility of the financial statements } \\
\text { by any means he deems appropriate. }\end{array}$ & $84.4 \%$ & 8 \\
\hline $\begin{array}{l}\text { The risk of incorrect financial statements increases if database systems are used without } \\
\text { proper control. }\end{array}$ & $83.5 \%$ & 9 \\
\hline $\begin{array}{l}\text { Failure to determine the responsibility of each employee according to his / her powers to } \\
\text { use the regulations relating to financial statements leads to increased risks. }\end{array}$ & $86.8 \%$ & 5 \\
\hline $\begin{array}{l}\text { Failure to determine the responsibility of each employee according to his / her powers to } \\
\text { use the financial statement systems increases the chances of information asymmetry. }\end{array}$ & $85.9 \%$ & 6 \\
\hline $\begin{array}{l}\text { It is not possible to publish financial statements of fake companies that do not exist on } \\
\text { the ground. }\end{array}$ & $81.2 \%$ & 13 \\
\hline $\begin{array}{l}\text { The appendices provide all additional information that is not shown in the financial } \\
\text { statements. }\end{array}$ & $80.6 \%$ & 14 \\
\hline
\end{tabular}

Table (5) show that there is an approval by the respondents on all paragraphs of the first axis "financial statements in companies", with a relative weight of $82.8 \%$, the highest two paragraphs were:

- The paragraph stipulates that "The financial statements are a key tool to know the financial position of the company, so they must be accurate and credible before being published by management", first order by relative weight $92.1 \%$. Accordingly, we conclude that the financial statements are a key tool to know the financial position of the company, so be sure of their accuracy and credibility before publishing them from management. The researcher attributes this to the fact that the financial statements clarify and interpret all the financial matters of the company since the beginning 
of the project. It indicates the basic plans for the implementation of the work and also alternative plans in the event of a deficit or malfunction during the implementation of the project. Therefore, the accuracy of the information provided in the lists should be verified so as not to cause problems such as inconsistencies in numbers or information about investors or beneficiaries that negatively affect the workflow.

- The paragraph stated that "the lack of credibility in the financial statements leads to mistrust in the company by investors, and does not give them the possibility to diagnose and make sound decisions." The second order according to the relative weight is $90.6 \%$. Consequently, we conclude that the lack of credibility in the financial statements leads to mistrust in the company by investors, and does not give them the possibility to diagnose and make sound decisions. The researcher attributes this to the necessity of credibility in the information and data presented in the financial statements when given to investors because any error or defect in the credibility and accuracy of the information may lead to loss of investor and loss of confidence in the company as a whole. This negatively affects the company's administrative and financial future.

- The results related to this axis are consistent with the Ahlam (2016) study, whose results indicated that the lists are a mirror of the financial position of the institution, and the Nkuhi study (2015), which indicated that sound financial statements make the decision of investors more confident in their decisions.

Analysis of results related to the second axis (financial decision-making in companies)

The researcher carried out the relative weight and the order of each paragraph of the second axis. The results were as shown in the following table:

Table 6 : The relative weight and rank of each paragraph of the second axis

\begin{tabular}{|c|c|c|}
\hline Paragraph & $\begin{array}{l}\text { Relative } \\
\text { weight }\end{array}$ & $\begin{array}{l}\text { Rank } \\
\text { ing }\end{array}$ \\
\hline Financial decisions aim at balancing return and risk. & $87.9 \%$ & 1 \\
\hline Financial decisions are intended to maximize the market value of an organization. & $86.2 \%$ & 2 \\
\hline $\begin{array}{l}\text { The importance of the resolution is greater the greater the need for information } \\
\text { collection. }\end{array}$ & $82.6 \%$ & 6 \\
\hline $\begin{array}{l}\text { Important decisions are characterized by the accuracy of the optimal alternative } \\
\text { choice. }\end{array}$ & $85.9 \%$ & 3 \\
\hline The Corporation makes investment decisions on current assets. & $80.6 \%$ & 11 \\
\hline The Corporation makes investment decisions on fixed assets. & $78.8 \%$ & 14 \\
\hline $\begin{array}{l}\text { The decision to invest in an enterprise is based on all the analysis and classification } \\
\text { of accounting and financial information relating to current and fixed assets to } \\
\text { predict future cash flows. }\end{array}$ & $85.6 \%$ & 4 \\
\hline $\begin{array}{l}\text { Investment decisions on fixed assets are affected based on expected future sales } \\
\text { covering the life of the fixed asset. }\end{array}$ & $79.4 \%$ & 13 \\
\hline $\begin{array}{l}\text { Investment decisions on fixed assets are affected based on the Corporation's strategy } \\
\text { and related capital expenditure. }\end{array}$ & $82.4 \%$ & 7 \\
\hline The institution depends on the alternatives available for financial decisions. & $79.7 \%$ & 12 \\
\hline The Foundation relies on a fixed rate policy. & $73.5 \%$ & 16 \\
\hline The Foundation adopts the policy of the rate of additional distributions. & $72.9 \%$ & 17 \\
\hline
\end{tabular}




\begin{tabular}{|l|c|c|}
\hline The organization depends on the alternatives available for dividend decisions. & $75.6 \%$ & 15 \\
\hline The Foundation depends on choosing the right mix from different sources of funding & $82.4 \%$ & 7 \\
\hline Financing decisions are about choosing the optimal financial structure & $84.4 \%$ & 5 \\
\hline $\begin{array}{l}\text { Financing decisions are based on internal financing as an important source in the } \\
\text { Company }\end{array}$ & $82.4 \%$ & 7 \\
\hline $\begin{array}{l}\text { Financing decisions depend on external financing as an important source in the } \\
\text { Company }\end{array}$ & $81.5 \%$ & 10 \\
\hline
\end{tabular}

Table (6) show that there is an approval by the respondents on all paragraphs of the second axis "making financial decisions in companies", with a relative weight of $81.3 \%$, and this was the highest two paragraphs:

- The paragraph stating that "financial decisions aim at balancing the return between risk and risk," ranked first by relative weight $87.9 \%$. Based on this, we conclude that financial decisions aim to achieve a balance between return and risk, and the researcher explains that sound financial decisions constitute a fertile ground for working to increase returns and raise the proportion of frequent and continuous. Based on the right financial decisions, the company can make sound decisions that avoid the range of risks that affect the future of the company.

- The paragraph stating that "financial decisions aim at maximizing the market value of the institution", second place according to the relative weight of $86.2 \%$. Accordingly, we conclude that financial decisions aim at maximizing the market value of the institution. The researcher explained that the right financial decisions to raise and increase the proportion of market value. This is because the right decisions carefully examine all aspects. It develops a set of alternative plans in the event of a deficit or malfunction and works to overcome them quickly. Thus, it achieves its objectives in maximizing its market value.

- The results related to this axis are consistent with the Ben Omar study (2015), whose results indicated that the financial decision is mainly related to the company's savings and the risks involved. It also agrees with the Ahlam study (2016), the results of which indicated that the analysis of financial statements contributes significantly to decision-making by knowing the institution's ability to finance its investments. And to bring in new investments. The extent to which its assets are convertible into cash as quickly as possible and at the lowest cost, which means its market value is certain to increase. They also differ with the Peltoniemi study (2017), which indicated that most organizations do not use the financial statement to make investment decisions. While the results of the current study agreed with the study Dabash and Khamili (2017), which indicated that any investment decision is based on a set of disclosures of accounting and financial information obtained through the financial statements. 
Analysis of the results related to the third axis (the effects of financial statement analysis on financial decision-making)

Table 7: The relative weight and rank of each paragraph of the third axis

\begin{tabular}{|c|c|c|}
\hline Paragraph & $\begin{array}{l}\text { Relative } \\
\text { weight }\end{array}$ & Ranking \\
\hline $\begin{array}{l}\text { The provision of financial statements and their use in financial decision- } \\
\text { making are essential. }\end{array}$ & $88.8 \%$ & 1 \\
\hline $\begin{array}{l}\text { Financial decision making depends largely on the quality and credibility of the } \\
\text { financial statements. }\end{array}$ & $88.5 \%$ & 3 \\
\hline $\begin{array}{l}\text { Financial statements contribute significantly to the process of making and } \\
\text { rationalizing financial decisions. }\end{array}$ & $85.6 \%$ & 11 \\
\hline $\begin{array}{l}\text { The financial statements of the Corporation contribute to the making of } \\
\text { executive decisions. }\end{array}$ & $86.8 \%$ & 8 \\
\hline $\begin{array}{l}\text { The financial statements contribute to the evaluation of the financial positions } \\
\text { of the company, and identify and measure costs. }\end{array}$ & $88.5 \%$ & 3 \\
\hline $\begin{array}{l}\text { The financial statements are used to make financing and borrowing decisions } \\
\text { in the Corporation. }\end{array}$ & $88.8 \%$ & 1 \\
\hline $\begin{array}{l}\text { Analysis of financial statements provides information about the status of the } \\
\text { institution in order to make the right financial decisions of various types. }\end{array}$ & $87.1 \%$ & 5 \\
\hline $\begin{array}{l}\text { The Corporation uses financial indicators to calculate the financial statements } \\
\text { in order to make a sound financial decision. }\end{array}$ & $87.1 \%$ & 5 \\
\hline $\begin{array}{l}\text { The Foundation relies on the analysis of financial statements to discover the } \\
\text { strengths and weaknesses, which contributes to the correctness of financial } \\
\text { decision-making. }\end{array}$ & $87.1 \%$ & 5 \\
\hline $\begin{array}{l}\text { The analysis of financial statements contributes to the recognition of the } \\
\text { deviations in the financial statements and improves the financial position } \\
\text { through sound decisions }\end{array}$ & $86.5 \%$ & 9 \\
\hline $\begin{array}{l}\text { The analysis of financial statements changes financial decisions periodically to } \\
\text { suit the objectives. }\end{array}$ & $86.2 \%$ & 10 \\
\hline $\begin{array}{l}\text { Analyzing financial statements helps owners make decisions that meet } \\
\text { objectives by avoiding unproductive elements. }\end{array}$ & $85.0 \%$ & 12 \\
\hline $\begin{array}{l}\text { The analysis of financial statements contributes to the estimation of future } \\
\text { needs that streamline the financial decision-making process. }\end{array}$ & $83.5 \%$ & 14 \\
\hline $\begin{array}{l}\text { The analysis of financial statements contributes to the estimation of the } \\
\text { actual costs of the business, which helps to make appropriate financial } \\
\text { decisions. }\end{array}$ & $82.1 \%$ & 15 \\
\hline $\begin{array}{l}\text { The analysis of financial statements contributes to a better possibility of } \\
\text { making decisions regarding the selection of appropriate opportunities and } \\
\text { alternatives. }\end{array}$ & $84.7 \%$ & 13 \\
\hline
\end{tabular}

Table (7) show that there is a strong approval by the respondents on all paragraphs of the third axis "the effects of analysis of financial statements on financial decision-making", with a relative weight of $86.4 \%$, and the highest two paragraphs:

- The paragraph states that "the provision and use of financial statements in financial decision-making is necessary and important". On the first order by relative weight $88.8 \%$, and accordingly we conclude that the provision of financial statements and their use in financial decisions is necessary and important. The researcher explains that a sound financial decision is made 
by the decision makers. It must be based on information of high quality and credibility in order to achieve the desired goals and objectives of these decisions, in the public interest of the company.

- The paragraph stating that "financial statements are used to make financing and borrowing decisions in the corporation" is ranked first, repeating by relative weight $88.8 \%$. Accordingly, we conclude that the financial statements are used to make financing and borrowing decisions in the Corporation. The researcher explains this because the financial statements contain all the details and financial matters followed in the company. It also includes the systems adopted by the company in the borrowing process and mechanisms. Which in turn helps in making sound financing decisions that must be followed by the institution because it certainly does not lead to financial losses or problems that may hinder its work.

- The results of the current study are consistent with those of Nkuhi (2015), which pointed to sound financial statements that make investors' decisionmaking more confident in their decision-making and encourage the use of financial statement analysis in investment decision-making. It also agrees with Dabash and Khamily's study (2017), which indicated that finance is the most important source of information they need when making their investment decision.

Test the significance of the relationship between the study axes using Pearson correlation coefficient.

Table 8: shows the Pearson correlation coefficient to test the relationship between the axes of study.

\begin{tabular}{|c|c|c|c|c|}
\hline \multirow{2}{*}{ The first axis } & Correlation coefficient & The third axis & The second axis & The first axis \\
\cline { 2 - 5 } & Significance level & 1.000 & $.726^{* *}$ & $.618^{* *}$ \\
\hline \multirow{2}{*}{ The second axis } & Correlation coefficient &. & .000 & .000 \\
\cline { 2 - 5 } & Significance level & &. & .000 \\
\hline \multirow{2}{*}{ The third axis } & Correlation coefficient & & & 1.000 \\
\cline { 2 - 5 } & Significance level & & & \\
\hline
\end{tabular}

It is clear from the previous table that there is a statistically significant correlation between the first axis "financial statements in companies". The second axis is "financial decision making in companies" by correlation coefficient 0.726. There is also a statistically significant correlation between the first axis "financial statements in companies". The third axis is "The Effects of Financial Statements Analysis on Financial Decision Making" by Correlation Coefficient 0.618. Also, there is a statistically significant correlation between the second axis "financial decision making in companies" and the third axis "the effects of financial statement analysis on decision making" by correlation coefficient 0.688 . 
Test the significance of personal characteristics of the study sample on each axis of the study:

First: Gender:

Table 9: The result of the $\mathrm{T}$ test for the test shows whether there are statistically significant differences in the responses of the respondents on the study axes, attributed to the gender variable (male - female).

\begin{tabular}{|c|c|c|c|c|c|c|}
\hline & Gender & Number & $\begin{array}{l}\text { Arithmetic } \\
\text { mean }\end{array}$ & $\begin{array}{l}\text { standard } \\
\text { deviation }\end{array}$ & $\mathrm{T}$ value & $\begin{array}{c}\text { Significance } \\
\text { level }\end{array}$ \\
\hline \multirow{2}{*}{$\begin{array}{c}\text { The first } \\
\text { axis }\end{array}$} & Male & 45 & 66.7556 & 8.84759 & \multirow{2}{*}{.662} & \multirow{2}{*}{.510} \\
\hline & Female & 23 & 65.2609 & 8.71893 & & \\
\hline \multirow{2}{*}{$\begin{array}{c}\text { The second } \\
\text { axis }\end{array}$} & Male & 45 & 70.0667 & 9.17110 & \multirow{2}{*}{1.060} & \multirow{2}{*}{.293} \\
\hline & Female & 23 & 67.6957 & 7.76610 & & \\
\hline \multirow{2}{*}{$\begin{array}{l}\text { The third } \\
\text { axis }\end{array}$} & Male & 45 & 65.2444 & 7.63710 & \multirow{2}{*}{.386} & \multirow{2}{*}{.701} \\
\hline & Female & 23 & 64.4783 & 7.96509 & & \\
\hline
\end{tabular}

It is clear from the previous table that there are no statistically significant differences in the responses of respondents towards the financial statements in the companies due to the type variable, where the value of the test $t=0.662$, and the level of significance is greater than 0.05. Also, there are no statistically significant differences in the responses of respondents towards financial decision making in companies due to the gender variable. The t-test value is 1.060 , and the significance level is greater than 0.05. Also, there were no statistically significant differences in the responses of the respondents towards the effects of analyzing the financial statements on the financial decision-making due to the type variable, where the test value was $t=0.386$. The significance level is greater than 0.05 . The researcher attributes this to the fact that the analysis of financial statements and financial decision-making does not depend mainly on gender. This is because the process as a whole is based on the information contained in these lists, its analysis and the decision based on it within a sequential work system in a clear path. It does not affect the type of individual who makes the decision.

Second: do you have a qualification or your job is related to financial management

Table 10 shows the result of the $\mathrm{T}$ test for the test whether there are statistically significant differences in the responses of the respondents on the axes of the study, attributed to whether the respondents hold a qualification or your job related to financial management.

\begin{tabular}{|c|c|c|c|c|c|c|}
\hline \multicolumn{2}{|c|}{$\begin{array}{l}\text { do you have a } \\
\text { qualification or your job is } \\
\text { related to financial } \\
\text { management }\end{array}$} & Number & $\begin{array}{c}\text { Arithmetic } \\
\text { mean }\end{array}$ & $\begin{array}{l}\text { standard } \\
\text { deviation }\end{array}$ & $\mathrm{T}$ value & $\begin{array}{c}\text { Significance } \\
\text { level }\end{array}$ \\
\hline \multirow{2}{*}{$\begin{array}{l}\text { The first } \\
\text { axis }\end{array}$} & Yes & 47 & 66.0638 & 9.18743 & \multirow{2}{*}{-.260} & \multirow{2}{*}{.796} \\
\hline & No & 21 & 66.6667 & 7.94565 & & \\
\hline \multirow{2}{*}{$\begin{array}{c}\text { The second } \\
\text { axis }\end{array}$} & Yes & 47 & 69.3830 & 8.79860 & \multirow{2}{*}{.166} & \multirow{2}{*}{.869} \\
\hline & No & 21 & 69.0000 & 8.80341 & & \\
\hline \multirow{2}{*}{$\begin{array}{l}\text { The third } \\
\text { axis }\end{array}$} & Yes & 47 & 65.2553 & 7.99312 & \multirow{2}{*}{.430} & \multirow{2}{*}{.669} \\
\hline & No & 21 & 64.3810 & 7.14476 & & \\
\hline
\end{tabular}


It is clear from the previous table that there are no statistically significant differences in the responses of respondents towards the financial statements in the companies due to whether the respondents have a scientific qualification or your job related to financial management, where the value of the test $t=0.260$, and the level of significance is greater than 0.05. Also, there are no statistically significant differences in the responses of the respondents towards making financial decisions in the companies attributed to whether the members of the sample hold a scientific qualification or your job related to financial management. The t-test value is 0.166 , and the significance level is greater than 0.05. Also, there are no statistically significant differences in the responses of the respondents towards the effects of analyzing the financial statements on financial decisionmaking due to whether the members of the sample hold a scientific qualification or your job related to financial management. The value of $\mathrm{t}=0.430$, and the significance level is greater than 0.05 .

Variance analysis test to verify the significance of the differences between the averages of the three axes divisions on the type of age, educational qualification, company scope and duration of experience

First: the academic qualification

Table 11: The analysis of variance analysis to verify the significance of differences between the averages of the three axes divisions on the type of each age

\begin{tabular}{|c|c|c|c|c|c|c|}
\hline Axis & $\begin{array}{c}\text { Source of } \\
\text { differences }\end{array}$ & Total squares & $\begin{array}{c}\text { Degrees of } \\
\text { freedom }\end{array}$ & $\begin{array}{l}\text { Average } \\
\text { squares }\end{array}$ & $\mathrm{F}$ value & Significance level \\
\hline \multirow{3}{*}{$\begin{array}{c}\text { The first } \\
\text { axis } \\
\text { The second } \\
\text { axis }\end{array}$} & Between groups & 334.989 & 2 & 167.495 & \multirow{3}{*}{2.261} & \multirow{3}{*}{.112} \\
\hline & Within groups & 4815.761 & 65 & 74.089 & & \\
\hline & Total & 5150.750 & 67 & & & \\
\hline \multirow{3}{*}{$\begin{array}{l}\text { The third } \\
\text { axis }\end{array}$} & Between groups & 123.293 & 2 & 61.646 & \multirow{3}{*}{.803} & \multirow{3}{*}{.452} \\
\hline & Within groups & 4989.943 & 65 & 76.768 & & \\
\hline & Total & 5113.235 & 67 & & & \\
\hline \multirow{3}{*}{$\begin{array}{l}\text { The first } \\
\text { axis }\end{array}$} & Between groups & 109.793 & 2 & 54.896 & \multirow{3}{*}{.924} & \multirow{3}{*}{.402} \\
\hline & Within groups & 3861.193 & 65 & 59.403 & & \\
\hline & Total & 3970.985 & 67 & & & \\
\hline
\end{tabular}

It is clear from the previous table that there are no statistically significant differences in the responses of respondents towards the financial statements in the companies attributed to the variable of educational qualification Where the value of the test $F=2.261$. The level of significance is greater than 0.05 , as well as the absence of statistically significant differences in the responses of respondents towards financial decision-making in companies due to the variable qualification. The test value was $\mathrm{F}=0.803$. The level of significance is greater than 0.05 . Also, there are no statistically significant differences in the responses of the respondents towards the effects of analyzing the financial statements on the financial decisionmaking due to the variable of scientific qualification. The value of the test is $\mathrm{F}=$ 0.924 , and the significance level is greater than 0.05 . The researcher attributes this to the fact that the scientific qualification does not play a large role in the process of influencing the financial decision-making process based on the analysis of financial statements, to the extent that it depends on the level of understanding and awareness of what is contained in the lists and the ability to 
analyze them. In addition to the important factor of personality in the financial decision-making process.

Second: Duration of service

Table 12: The analysis of variance analysis to verify the significance of the differences between the averages of the three axis divisions on the type of each service period

\begin{tabular}{|c|c|c|c|c|c|c|}
\hline Axis & $\begin{array}{c}\text { Source of } \\
\text { differences }\end{array}$ & Total squares & $\begin{array}{c}\text { Degrees of } \\
\text { freedom }\end{array}$ & $\begin{array}{l}\text { Average } \\
\text { squares }\end{array}$ & $\mathrm{F}$ value & Significance level \\
\hline The first & Between groups & 592.265 & 3 & 197.422 & \multirow{3}{*}{2.772} & \multirow{3}{*}{.049} \\
\hline axis & Within groups & 4558.485 & 64 & 71.226 & & \\
\hline $\begin{array}{c}\text { The second } \\
\text { axis }\end{array}$ & Total & 5150.750 & 67 & & & \\
\hline \multirow{3}{*}{$\begin{array}{l}\text { The third } \\
\text { axis }\end{array}$} & Between groups & 268.336 & 3 & 89.445 & \multirow{3}{*}{1.182} & \multirow{3}{*}{.324} \\
\hline & Within groups & 4844.899 & 64 & 75.702 & & \\
\hline & Total & 5113.235 & 67 & & & \\
\hline \multirow{3}{*}{$\begin{array}{l}\text { The first } \\
\text { axis }\end{array}$} & Between groups & 240.932 & 3 & 80.311 & \multirow{3}{*}{1.378} & \multirow{3}{*}{.258} \\
\hline & Within groups & 3730.053 & 64 & 58.282 & & \\
\hline & Total & 3970.985 & 67 & & & \\
\hline
\end{tabular}

It is clear from the previous table that there are statistically significant differences in the responses of respondents towards the financial statements in the companies attributed to the variable duration of service. The value of the test is $\mathrm{F}=2.772$, and the significance level is less than 0.05. Where the researcher believes that the variable duration of service generates the experience and knowledge and extrapolation and forecast associated with the analysis of financial statements, while there were no significant differences in the responses of respondents towards making financial decisions in companies attributable to the variable duration of service. The value of the test is $\mathrm{F}=1.182$, and the significance level is greater than 0.05. Also, there are no statistically significant differences in the responses of the respondents towards the effects of analyzing the financial statements on the financial decision-making due to the variable of the service period. The test value is $\mathrm{F}=0.258$, and the significance level is greater than 0.05 . The researcher attributes this to the fact that the systematic process associated with the analysis of the lists and financial decision-making based on it requires awareness of what is in it, as this process is linked to the contents of the financial statements that are easily read by decision makers.

Third: Age group

Table 13: The analysis of variance analysis to verify the significance of differences between the averages of the three axes divisions on the type of each age group

\begin{tabular}{|c|c|c|c|c|c|c|}
\hline Axis & $\begin{array}{c}\text { Source of } \\
\text { differences }\end{array}$ & Total squares & $\begin{array}{c}\text { Degrees of } \\
\text { freedom }\end{array}$ & $\begin{array}{l}\text { Average } \\
\text { squares }\end{array}$ & $\mathrm{F}$ value & Significance level \\
\hline The first & Between groups & 484.054 & 3 & 161.351 & \multirow{3}{*}{2.213} & \multirow{3}{*}{.095} \\
\hline axis & Within groups & 4666.696 & 64 & 72.917 & & \\
\hline $\begin{array}{c}\text { The second } \\
\text { axis }\end{array}$ & Total & 5150.750 & 67 & & & \\
\hline \multirow{3}{*}{$\begin{array}{l}\text { The third } \\
\text { axis }\end{array}$} & Between groups & 176.567 & 3 & 58.856 & \multirow{3}{*}{.763} & \multirow{3}{*}{.519} \\
\hline & Within groups & 4936.669 & 64 & 77.135 & & \\
\hline & Total & 5113.235 & 67 & & & \\
\hline The first & Between groups & 316.298 & 3 & 105.433 & 1.846 & .148 \\
\hline
\end{tabular}


axis

\begin{tabular}{|c|l|l}
\hline Within groups & 3654.687 & 6 \\
\hline Total & 3970.985 & 67 \\
\hline
\end{tabular}

\begin{tabular}{|r|r}
\hline 64 & 57.104 \\
\hline 67 &
\end{tabular}

It is clear from the previous table that there are no statistically significant differences in the responses of respondents towards the financial statements in the companies due to the age group variable. The value of the test is $\mathrm{F}=2.213$, and the significance level is greater than 0.05. Also, there are no statistically significant differences in the responses of respondents towards financial decision making in companies due to the age group variable. Where the value of the test is $\mathrm{F}=0.763$, and the significance level is greater than 0.05. Also, there are no statistically significant differences in the responses of the respondents towards the effects of analyzing the financial statements on the financial decision-making due to the age group variable. The value of the test is $\mathrm{F}=1.846$, and the significance level is greater than 0.05. The researcher attributes this to the fact that a variable does not necessarily judge the preference of financial decision-making or analysis of financial statements, and the evidence about it many. Young decisionmakers can have more creativity, innovation and insight than older ones.

Fourth: The size of the company

Table 14: The analysis of variance analysis to verify the significance of the differences between the averages of the three axis divisions on the type of each company size

\begin{tabular}{|c|c|c|c|c|c|c|}
\hline Axis & $\begin{array}{c}\text { Source of } \\
\text { differences }\end{array}$ & Total squares & $\begin{array}{c}\text { Degrees of } \\
\text { freedom }\end{array}$ & $\begin{array}{l}\text { Average } \\
\text { squares }\end{array}$ & $\mathrm{F}$ value & Significance level \\
\hline \multirow{3}{*}{$\begin{array}{l}\text { The first } \\
\text { axis } \\
\text { The second } \\
\text { axis }\end{array}$} & Between groups & 1.496 & 2 & .748 & \multirow{3}{*}{.009} & \multirow{3}{*}{.991} \\
\hline & Within groups & 5149.254 & 65 & 79.219 & & \\
\hline & Total & 5150.750 & 67 & & & \\
\hline \multirow{3}{*}{$\begin{array}{l}\text { The third } \\
\text { axis }\end{array}$} & Between groups & 266.294 & 2 & 133.147 & \multirow{3}{*}{1.786} & \multirow{3}{*}{.176} \\
\hline & Within groups & 4846.941 & 65 & 74.568 & & \\
\hline & Total & 5113.235 & 67 & & & \\
\hline \multirow{3}{*}{$\begin{array}{l}\text { The first } \\
\text { axis }\end{array}$} & Between groups & 172.103 & 2 & 86.051 & \multirow{3}{*}{1.472} & \multirow{3}{*}{.237} \\
\hline & Within groups & 3798.882 & 65 & 58.444 & & \\
\hline & Total & 3970.985 & 67 & & & \\
\hline
\end{tabular}

It is clear from the previous table that there are no statistically significant differences in the responses of respondents towards the financial statements in the companies due to the size of the company. The value of the test is $\mathrm{F}=0.009$, and the significance level is greater than 0.05. Also, there are no statistically significant differences in the responses of respondents towards making financial decisions in companies due to the size of the company. The value of the test is $\mathrm{F}$ $=1.786$, and the significance level is greater than 0.05. Also, there are no statistically significant differences in the responses of the respondents towards the effects of analyzing the financial statements on financial decision-making due to the size of the company. The value of the test is $\mathrm{F}=1.472$, and the significance level is greater than 0.05 . The researcher attributes this to the fact that there is a system used in most companies, regardless of the size of the scale, in which the process of analysis of the lists and financial decision-making, so as to maintain the company no matter how large or small on its continuity. 


\title{
Conclusion and Recommendations
}

\author{
Summary of results:
}

- There is approval by the respondents on all paragraphs of the first axis "financial statements in companies", with a relative weight of $82.8 \%$.

- There is approval by the sample on all paragraphs of the second axis "financial decision-making in companies", with a relative weight of $81.3 \%$.

- There is strong approval by the respondents on all paragraphs of the third axis "the effects of analysis of financial statements on financial decisionmaking", with a relative weight of $86.4 \%$.

- The financial statements are a key tool to know the financial position of the company, so be sure of their accuracy and credibility before publication.

- The lack of credibility in the financial statements leads to mistrust in the company by investors, and does not give them the possibility to diagnose and make sound decisions.

- The credibility of the financial statements is verified by the auditors before being presented to the beneficiaries.

- Failure to determine the responsibility of each employee according to his / her powers to use the regulations relating to financial statements increases the risk.

- Financial decisions aim to achieve a balance between return and risk.

- Financial decisions are aimed at maximizing the market value of an organization.

- The provision of financial statements and their use in financial decisionmaking is essential.

- The analysis of financial statements provides information on the status of the institution in order to make the right financial decisions of various kinds.

- The institution uses the financial indicators to calculate the financial statements in order to make the right financial decision.

- There is a statistically significant correlation between the first axis "financial statements in companies" and the second axis "financial decisions in companies" according to correlation coefficient 0.726 .

- There is a statistically significant correlation between the first axis "financial statements in companies" and the third axis "the effects of analysis of financial statements on financial decision-making" by correlation coefficient 0.618 .

- There is a statistically significant correlation between the second axis "financial decision making in companies" and the third axis "the effects of financial statement analysis on financial decision making" by correlation coefficient 0.688 . There are no statistically significant differences in the respondents' responses towards the financial statements in the companies due to the gender variable.

- There are no statistically significant differences in the responses of the sample towards financial decision-making in companies due to the gender variable. 
- There are no statistically significant differences in the responses of the sample towards the effects of analysis of financial statements on financial decision-making due to the gender variable.

- There are no statistically significant differences in the respondents' responses to the financial statements in the companies due to whether the sample members have a scientific qualification or your job related to financial management.

- There are no statistically significant differences in the responses of respondents towards financial decision making in companies due to whether the respondents have a scientific qualification or your job related to financial management.

- There are no statistically significant differences in the responses of the respondents towards the effects of analyzing the financial statements on financial decision-making due to whether the sample members hold a scientific qualification or your job related to financial management.

- There are no statistically significant differences in the responses of the sample towards the financial statements in the companies due to the qualification variable.

- There are no statistically significant differences in the responses of respondents towards making financial decisions in companies due to the variable of educational qualification.

- There are statistically significant differences in the responses of the respondents towards the financial statements in the companies due to the variable duration of service.

- There are no statistically significant differences in the responses of the sample towards making financial decisions in the companies due to the service variable.

- There are no statistically significant differences in the responses of the respondents towards the effects of analyzing the financial statements on financial decision-making due to the variable duration of service.

- There are no statistically significant differences in the responses of respondents towards the financial statements in the companies due to the age group variable.

- There are no statistically significant differences in the responses of the sample towards financial decision making in companies due to the service variable.

- There are no statistically significant differences in the responses of the respondents towards the effects of analyzing the financial statements on the financial decision-making due to the variable of service life

- There are no statistically significant differences in the responses of the sample members towards the financial statements in the companies due to the age group variable.

- There are no statistically significant differences in the responses of the sample towards financial decision making in the companies attributed to the age group.

- There are no statistically significant differences in the responses of the respondents towards the effects of analyzing financial statements on financial decision-making due to the age group variable.

- There are no statistically significant differences in respondents' responses to the financial statements in the companies due to the size of the company. 
- There are no statistical differences in the sample responses towards financial decision making in companies due to the size of the company.

\section{Conclusions}

- Any financial decision is based on a set of correct information obtained from the analysis of financial statements. The financial decision maker in the companies after obtaining this information starts at the stage of making the appropriate financial decision. By choosing the right alternatives to maximize your return with the least risk.

- The financial statements should contain various additional information needed by the investor, which contributes to increasing confidence in the information received from the analysis of the financial statements. In addition to consistency in following accounting methods. The multiplicity of methods makes it difficult to compare a similar institution to another. This also gives an unfair picture of the financial position and performance of the institution and thus makes a misleading financial decision.

- Accurate information should be provided on the alternatives available to the financial decision, in order to achieve greater quality of financial decision and timely delivery of information. This will increase the appropriate decision making and honest information resulting from the analysis of the lists to enable financial decision makers to make the appropriate decisions.

\section{Recommendations}

Based on the researcher's findings, he recommends the following:

1.Many forums, conferences and forums should be organized in order to clarify the mechanism of preparing the financial statements and how to analyze them.

2.It is necessary to make financial decision makers aware of the importance of financial statements in the financial decision-making process.

3.It is necessary to disclose the financial statements well that helps the users of the financial statements to use them at the lowest cost.

4.It is necessary to use the analysis tools of the financial statements before making a financial decision based on the analytical vision of the institution.

\section{Acknowledgments}

The author's expression is a profound thank you to Dr. Mohamed Ibrahim for his guidance in preparing this research 


\section{References:}

Abdulhakim, Soleimani (2013). The Role of Accounting Information System in Financial Decision Making, Master Thesis, Faculty of Economic, Commercial and Management Sciences, Mohamed Khedr University, Biskra, Algeria.

Abu Huwaidi, Nihad (2011). The Role of Accounting Information in Rationalizing Capital Expenditure Decisions: An Empirical Study on Companies Listed in the Palestine Exchange. Master Thesis, Faculty of Commerce, Islamic University, Palestine.

Abu Kuhail, Ahmad (2014). The Role of Finance Manager in Strategy Planning and Budgeting: An Empirical Study on UAE Real Estate Companies. Master Thesis, Department of Accounting and Finance, Faculty of Business, Middle East University, Jordan.

Ahlam, Qasawi (2016). The Role of Financial Statements Analysis in Financial Decision Making: A Case Study of the Greater Mills Corporation of South Omash. Master Thesis, Faculty of Economic and Commercial Sciences and Management Sciences, University of Mohamed Khedr Biskra, Algeria.

Ahmed, Sameh (2010). Discover fraud and manipulation of financial statements. Saudi Arabia: King Fahd National Library.

Al Shaib, Duraid Kamel (2011). Introduction to Contemporary Financial Management. Akkam: Dar Al-Massira.

Al-Ali, Asaad Hamid (2010). Financial management: scientific and applied foundations. Amman: Wael Publishing \& Distribution House.

Al-Mahli, Nasser (2009). Characteristics of accounting information and its effects in making decisions. Master Thesis, Master Thesis, Faculty of Economics and Management Sciences, Department of Accounting, Hadj Lakhdar University, Algeria.

Al-Nabahin, Yusuf (2008). Evaluating the performance of financial management in NGOs working in the Gaza Strip. Master Thesis, Faculty of Commerce, Islamic University, Palestine.

Al-Naimi, Adnan Tayeh, and Al-Tamimi, Arshad Fouad (2009). Advanced Financial Management, Jordan: Dar Al Yazouri.

Ayyash, Jaber Mohammed (2008). The reality of the use of quantitative methods in decision-making and problem-solving among NGOs in Gaza Strip, Master Thesis, Faculty of Commerce, Islamic University, Palestine.

Ben Omar, Mohammed (2016). The Role of Financial Statements According to the Financial Accounting System in Financial Decision Making, MA Thesis, Faculty of Economic, Commercial and Management Sciences, Martyr Hamma Lakhdar El-Oued University, Algeria

Chiha, K. (2009). Finance Dentreprise approche stategique. Houma edition, Algeria.

Dabash, Amira, Khamili, Farid (2017). The Contribution of Financial Statements to Investment Decisions in the Stock Market: A Case Study of Investors in the Algiers Stock Exchange, Journal of Business and Trade Economics, Vol. 3, pp. 20-42.

Hamdan, Agila (2013). The effectiveness of the accounting information system in the financial performance of the economic institution. Master Thesis, Faculty of Information Systems and Management Control, University of Kasidi Merbah Ouargla, Algeria.

Hanafi, Abdul Ghaffar (2005). Fundamentals of Finance and Financial Management. Alexandria: University House.

Hanan, Radwan (2005). Introduction to Accounting Theory: The Intellectual Framework - Practical Applications. Amman: Wael Publishing House.

Hanan, Radwan Hilla, Al-Baldawi, Nizar Fuleih (2009). Principles of Financial Accounting: Measurement and disclosure in financial statements. Oman: Ithraa Publishing \& Distribution.

Jalila, Ben Lamb (2009). The role of financial information in evaluating the financial performance of the institution and making decisions. Master Thesis, Faculty of Economic, Commercial and Management Sciences, University of Bouguerra, Boumerdes, Algeria.

Khaled, Bouchareb (2014). The role of multi-objective linear programming model in productive decision making. Unpublished Master Thesis, Faculty of Economic, Commercial and Management Sciences, Mohamed Khedr University, Biskra, Algeria.

Khawla, Arag (2016). "Contribution of Financial Budget Analysis to Financial Decision Making: Case Study of the Sonelgaz Foundation - Biskra". Master Thesis, Faculty of Economic and Commercial Sciences and Management Sciences, University of Mohamed Khedr Biskra, Algeria.

Matar, Mohammed (2006). Recent trends in financial and credit analysis. 1st Floor, Amman: Wael Publishing House.

Nawaf, Canaan (2003). Making administrative decisions between theory and practice. Amman: Culture House for Publishing and Distribution.

Nkuhi, (2015(. The Role of Financial Statements in Investment Decision Making a Case of Tanga Port Authority'. Master of Business Administration, Mzumbe University. 
Obeidat, Mohammed, and Abu Nassar, Mohammed, and the ovaries, Oqla (1999). Methodology of scientific research rules, stages and applications-Faculty of Economics and Administrative Sciences British University. Amman: Wael Publishing House.

Obeidi, Hassanein Hamid, and Abdul Razek Noor (2016). Financial analysis of financial statements using computer sample of economic units. Journal of the University College of Heritage, p 19, pp. 108-129.

Peltoniemi, Janne (2017). The Role of Financial Statements in Investment Decision Making a Case of Tanga Port Authority', Unpublished Master of Business Administration, Centria University of Applied Sciences.

Sami, Lazhar Mohammed (2012). Financial analysis of financial statements according to the financial accounting system. Master Thesis, Faculty of Financial Management, University of Mentouri Constantine, Algeria.

Sufian, Suleiman, and Shara, Majeed (2002). accounting administration. Amman: Dar Al Shorouk for Publishing \& Distribution.

Yusuf, Yusuf (2012). Financing in the economic institution. Alexandria: House of University Education.

Zogheib, Malika, and Boujada, Elias (2009). Studying the Fundamentals of Decision Making in the Economic Foundation, International Decision-Making Forum in the Economic Institution, Faculty of Economic, Commercial and Management Sciences, University of M'Sila, Algeria. 